\title{
Determination of pKa Values of Some Auxins in Methanol-Water Mixtures by Reversed Phase Liquid Chromatography and Potentiometric Methods
}

\author{
Mustafa Kelen ${ }^{*, a}$ and Nurullah Sanli ${ }^{b}$ \\ ${ }^{a}$ Department of Horticulture, Faculty of Agriculture, Süleyman Demirel University, 32260, Isparta, Turkey \\ ${ }^{b}$ Department of Chemistry, Faculty of Science and Arts, Hitit University, 19040, Corum, Turkey
}

\begin{abstract}
Os hormônios das plantas são de vital importância para o seu funcionamento normal. As auxinas são uma classe de fito-hormônios envolvidas em muitos aspectos do crescimento. Os ácidos indol3-acético (IAA), indol-3-pirúvico (IPA) e indol-3-lático (ILA) são auxinas com funções biológicas estimulantes do processo de crescimento, tais como elongação e divisão. Neste estudo, os valores $\mathrm{pK}_{\mathrm{a}}$ de IAA, IPA e ILA em misturas de metanol-água a 30\%, $40 \%$ e 50\% (v/v) foram determinados usando potenciometria, cromatografia líquida (LC) e metodologia LC-DAD. Valores de $\mathrm{pK}_{\mathrm{a}}$ em água, preditos pelo método SPARC também foram investigados.
\end{abstract}

Plant hormones are of vital importance for the normal functioning of plants. Auxins are a class of phytohormones involved in many aspects of plant growth. Indole-3-acetic acid, (IAA), indole-3-pyruvic acid (IPA) and indole-3-lactic acid (ILA) are auxins with biological functions stimulating growth processes such as cell elongation and division. In this study, the $\mathrm{pK}_{\mathrm{a}}$ values of IAA, IPA and ILA in 30\%, 40\% and 50\% (v/v) methanol-water mixtures were determined using potentiometry, liquid chromatography (LC) and LC-DAD methodology. Also, the $\mathrm{pK}_{\mathrm{a}}$ values in water predicted by the SPARC on-line calculator have been investigated.

Keywords: dissociation constants, LC, LC-DAD, methanol-water mixtures, plant hormones, potentiometry

\section{Introduction}

Dissociation constants are important physicochemical parameters of a substance, and the knowledge of these parameters is of fundamental importance in a wide range of applications and research areas. The chromatographic retention and electrophoretic behaviour of ionizable compounds strongly depend on the $\mathrm{pK}_{\mathrm{a}}$ of the compound and the mobile phase $\mathrm{pH}$. Therefore, a satisfactory knowledge of the acid-base behaviour of substances in a hydro-organic media such as methanol $(\mathrm{MeOH}) /$ water is essential to predict the influence of $\mathrm{pH}$ on selectivity and retention in liquid chromatography (LC), and also to optimize analytical procedures for the separation of ionizable compounds by various techniques. ${ }^{1-3}$

Methanol is one of the most utilized solvents due to its good solvating properties of organic compounds. In addition, due to its relatively high dielectric constant $(\varepsilon=32.63)$ dissolves ionic solutes and prevents ion-pair

*e-mail: mkelen32@yahoo.com formation at very high solute concentrations. Among the organic solvents, methanol is the closest one to water in terms of its structure and properties and, therefore, acidic dissociation in methanol occurs in an analogous way to that in aqueous solution. However, methanol can solve a wide majority of organic acids more effectively than water and in many cases it is a more suitable solvent for the determination of the dissociation constants. ${ }^{4}$

There are a large spectrum of $\mathrm{pK}_{\mathrm{a}}$ determination techniques including potentiometry, conductivity, calorimetry, UV-Vis and NMR spectrometry, mass spectrometry, liquid chromatography, capillary zone electrophoresis, and software computational predictions. Among these techniques, the potentiometric titration is most economical of time particularly for $\mathrm{pK}_{\mathrm{a}}$ determination. If due care is taken, this technique is accurate and has good reproducibility. Moreover, UV-Vis absorption spectrometry has still been used widely for the determination of dissociation constants, because of their accuracy and reproducibility. ${ }^{5}$ Moreover, the use of computer programs for the refinement of dissociation constants allows the 
different $\mathrm{pK}_{\mathrm{a}}$ values of polyprotic substances to be determined, even when they are very close..$^{6-9}$

In the last decade, some alternative techniques have been developed, based on separation methods such as liquid chromatography (LC) and capillary zone electrophoresis (CZE). The determination of $\mathrm{pK}_{\mathrm{a}}$ value by liquid chromatography is based on the relationship between the capacity factors and the $\mathrm{pH}$ values of the mobile phase..$^{10,11}$ This procedure is limited by the LC column working $\mathrm{pH}$ range. The optimum conditions being when the $\mathrm{pK}_{\mathrm{a}}$ corresponds to the equilibrium between a neutral species and a charged species (this is, $\mathrm{H}_{2} \mathrm{~A}^{+} \leftrightarrow \mathrm{HA}, \mathrm{HA} \leftrightarrow \mathrm{A}^{-}$, or $\mathrm{B} \leftrightarrow \mathrm{HB}^{+}$), but since the main objective of $\mathrm{pK}_{\mathrm{a}}$ determination by $\mathrm{LC}$ is the optimization of chromatographic separations, this method is perfectly adequate for its purpose.

Recently, a new procedure has been developed in which $\mathrm{LC}$ and CZE methodologies are used for $\mathrm{pK}_{\mathrm{a}}$ determination in combination with a diode array detector (DAD) for absorbance measurements. ${ }^{12-14}$ In these cases, the $\mathrm{pK}_{\mathrm{a}}$ values can be determined from the absorbance spectra obtained at the maxima of the chromatographic or electrophoretic peaks. In this way, $\mathrm{pK}_{\mathrm{a}}$ values can be obtained from two independent methods: capacity factor $/ \mathrm{pH}$ data and spectra/pH data in $\mathrm{LC}$ procedures (LC-DAD), and mobility/pH data and spectra/pH data in CZE procedures (CZE-DAD). In most of these methods a physical property of the analyte is measured as a function of the $\mathrm{pH}$ of the solution and the data is used for the determination of $\mathrm{pKa}$ values. In addition, the $\mathrm{pK}_{\mathrm{a}}$ values in water predicted by the SPARC on-line calculator have been investigated. ${ }^{15,16}$ The program estimates the $\mathrm{pK}_{\mathrm{a}}$ values of any organic compound solely from its chemical structure. SPARC is available free of charge on the internet.

Hormones occur in plant material at very low concentrations $\left(\mathrm{ng} \mathrm{g}^{-1}\right)$, together with many other compounds. Accurate analysis of trace quantities of hormones in plant extracts which are exceedingly complex multicomponent mixtures is a major problem. To obtain reliable information to identify and measure plant hormones special techniques are needed. ${ }^{17}$ Plant hormones are of vital importance for the normal functioning of plants. Their very low concentrations (ppm, ppb) trigger basic developmental processes such as cell division, enlargement and differentiation, organ formation, seed dormancy and germination, leaf and organ senescence and abscission. Auxins are a class of phytohormones which are involved in many aspects of plants growth. ${ }^{18,19}$

Indole-3-acetic acid, (IAA), indole-3-pyruvic acid (IPA) and indole-3-lactic acid (ILA) are auxins with biological functions, stimulating growth processes such as cell elongation and division. ${ }^{20}$
Most plant hormones have acidic and/or basic functionalities. Their ionization state is controlled by both solution $\mathrm{pH}$ and acidic dissociation constants of plant hormones (i.e., $\mathrm{pK}_{\mathrm{a}}$ values). Auxines are relatively hydrophobic compounds containing a carboxylic group. Different chemical species such as cationic, neutral or anionic forms often have vastly different properties with respect to water solubility, volatility, UV absorption, and reactivity. Unfortunately, the $\mathrm{pK}_{\mathrm{a}}$ values of many relevant plant hormones are either not known accurately or not available at all. Therefore, there is an important need to determine the dissociation constants for these compounds to essentially facilitate occurrence, effects, and control of plant hormones in scientific studies.

In this study, we have determined the $\mathrm{pK}_{\mathrm{a}}$ values of some plant hormones including indole-3-acetic acid (IAA), indole-3-pyruvic acid (IPA) and indole-3-lactic acid (ILA) in $30 \%, 40 \%$ and $50 \%(\mathrm{v} / \mathrm{v}) \mathrm{MeOH} /$ water binary mixtures using potentiometric and liquid chromatographic (LC and LC-DAD) methods. For practical reasons, the potentiometric determinations were performed at $30 \%, 40 \%$, and $50 \%$ (v/v) $\mathrm{MeOH} /$ water content, whereas the chromatographic determinations of $\mathrm{pK}_{\mathrm{a}}$ values were at $30 \%(\mathrm{v} / \mathrm{v}) \mathrm{MeOH} /$ water content. The dissociation constants will be useful for a thorough understanding of certain chemical phenomena such as activity and reacting rates, biological uptake and receptor binding of substances at the molecular level. Also, $\mathrm{pK}_{\mathrm{a}}$ values can be used for the development of separation methods of auxines based on liquid chromatography and electrophoresis in $\mathrm{MeOH} /$ water mixtures.

\section{Experimental}

\section{Chemicals and reagents}

All chemicals used were of analytical grade unless otherwise indicated. Plant hormones (IAA, IPA and ILA) were purchased from Sigma and used without further purification. Water with conductivity lower than $0.05 \mu \mathrm{S} \mathrm{cm}^{-1}$ was obtained via a Milli Q water purification system (Milli Pore Corp.). Methanol (HPLC grade) was supplied by Merck. Potassium hydrogen phthalate dried at $110^{\circ} \mathrm{C}$ before use, (Fluka), hydrochloric acid (Merck), phosphoric acid (Merck) and potassium bromide (Merck) were used.

\section{Potentiometric measurements}

Stock $0.025 \mathrm{~mol} \mathrm{~L}^{-1}$ potassium hydroxide solutions were prepared in each $\mathrm{MeOH} /$ water mixture from $1 \mathrm{~mol} \mathrm{~L}^{-1}$ potassium hydroxide solution (Titrisol, Merck) by dilution. Hydrochloric acid solutions were prepared by dilution 
from $1 \mathrm{~mol} \mathrm{~L}^{-1}$ hydrochloric acid (Titrisol, Merck) in each $\mathrm{MeOH} /$ water mixture. The ionic strengths of all working solutions were adjusted at $0.1 \mathrm{~mol} \mathrm{~L}^{-1}$ with potassium chloride (Merck).

\section{Chromatographic measurements}

Standard stock solutions of IAA, IPA, and ILA were freshly prepared in $\mathrm{MeOH}$ at a concentration of approximately $200 \mathrm{mg} \mathrm{L}^{-1}$ and stored in dark colour bottles in refrigerator $\left(4^{\circ} \mathrm{C}\right)$. Working solutions were diluted with corresponding mobile phase to $10 \mathrm{mg} \mathrm{L}^{-1}$. These solutions were passed through a $0.45 \mu \mathrm{m}$ nylon filter membrane (MSI) before injections. The hold-up time, $\mathrm{t}_{0}$ was measured for every mobile phase composition by injection of $0.01 \%$ potassium bromide solution.

\section{Apparatus}

In order to obtain the $\mathrm{pK}_{\mathrm{a}}$ values using potentiometric technique, potential values of the potentiometric cell were measured with a $\mathrm{pH} /$ ion analyser (Model Metler-Toledo MA $235)$ with combined electrode system $( \pm 0.1 \mathrm{mV})$. The cell was thermostated externally at $25.0^{\circ} \mathrm{C} \pm 0.1$ with a water bath cooler system (HETO CBN 8-30 and temperature control unit HETO HMT 200), and the test solution was stirred magnetically under a continuous flow of purified nitrogen. Each system was titrated three times.

A chromatographic system consisting of a pump (Shimadzu Model LC 10 ADVP) with an auto injector (SIL 10 AD VP) and a diode array detector system (SPDM 10 A DAD) was used. The equipment had a column oven (CTO 10 AVP) and degassing system (DGU 14 A). The column used was Luna $\mathrm{C} 18(150 \times 4.6 \mathrm{~mm}$ ID). Flow rate was $0.8 \mathrm{~mL} \mathrm{~min}^{-1}$ and the column temperature was $30^{\circ} \mathrm{C}$.

\section{Procedures}

\section{Potentiometric procedure}

The glass electrode was stabilized in the $\mathrm{MeOH} /$ water mixture before potentiometric measurements were taken step by step. The stabilization criterion for the potential readings was $0.2 \mathrm{mV}$ within $120 \mathrm{~s}$. In all instances, the electrode system gave stable and reproducible potentials within $5 \mathrm{~min}$. The standardization of the electrode system was carried out each time in $\mathrm{MeOH} /$ water mixtures (background solution) using Gran's method. ${ }^{21,22}$ For this purpose, the electrode was immersed in these mixtures (20 $\mathrm{mL}$ and $0.1 \mathrm{~mol} \mathrm{~L}^{-1}$ ionic strength). Usually, 10 or 12 additions of hydrochloric acid were adequate for $\mathrm{E}^{\mathrm{o}}$ value to be accurately determined. These additions provide change of initial $\mathrm{pH}$ of the background solution from $\mathrm{pH} 2$ which is a value about two units lower than the $\mathrm{pK}_{\mathrm{a}}$ of the compounds studied. The potential was allowed to stabilize after each addition of acid, and the potential values obtained were used to calculate the standard potential of the cell, $\mathrm{E}^{0}$.

The $\mathrm{pK}_{\mathrm{a}}$ values of auxins were determined by titration of the appropriate solutions of these compounds $\left(3 \mathrm{mmol} \mathrm{L}^{-1}\right)$ in $30 \%(\mathrm{v} / \mathrm{v}), 40 \%(\mathrm{v} / \mathrm{v})$ and $50 \%(\mathrm{v} / \mathrm{v}) \mathrm{MeOH} /$ water, using $\mathrm{KOH}$ solution as titrant, in $0.1 \mathrm{~mol} \mathrm{~L}^{-1}$ ionic strength $(\mathrm{KCl})$ according to the criteria described by IUPAC. ${ }^{23,24}$ Carbon dioxide dissolved in titrating solution was purged out with nitrogen gas. The auxin solution was completely mixed with a magnetic stirrer. Titration was carried out in triplicate at constant temperature $\left(25.0 \pm 0.1{ }^{\circ} \mathrm{C}\right)$ to ensure reproducibility. Dropwise addition of $\mathrm{KOH}$ solution was performed by Biohit-Proline pipetters (Biohit Corp. Finland). The calculation of $\mathrm{pK}_{\mathrm{a}}$ values requires an iterative cycle for each point of the potentiometric titration at which e.m.f. was measured and were carried out by using the program written in Pascal, PKPOT. ${ }^{7}$ This is a non-linear least squares program designed to take into account the correction of activity coefficients, allowing the refinement of thermodynamic equilibrium constants in aqueous, hydro organic and non-aqueous media.

\section{Chromatographic method}

Throughout the study, the mobile phase assayed was $\mathrm{MeOH} /$ water at a concentration of $30 \%(\mathrm{v} / \mathrm{v}) \mathrm{MeOH} /$ water. Phosphoric acid was used as a buffer component because of its appropriate $\mathrm{pK}_{\mathrm{a}}$ values and the symmetrical peak shape of the auxins in this buffer solution. The $\mathrm{pH}$ of the mobile phase was adjusted between 3.5 and 7.0 with sodium hydroxide. The use of $\mathrm{MeOH} /$ water mixtures requires the correct measurements of the $\mathrm{pH}$ in studied media. Measurements are performed in a similar way to those performed in water following IUPAC standardization guidelines. ${ }^{23,24}$ Potassium hydrogen phthalate solution $\left(0.05 \mathrm{~mol} \mathrm{~kg}^{-1}\right)$ dissolved in the appropriate $\mathrm{MeOH} /$ water medium was used as a reference value standard (RVS) for calibration of $\mathrm{pH} /$ ion analyzer. ${ }^{25,26} \mathrm{pH}$ measurements of the mobile phases were performed in triplicate to ensure stability and reproducibility of the potentiometric system. Thus, the $\mathrm{pH}_{\mathrm{x}}$ of a solution was determined using the following equation.

$\mathrm{pH}_{\mathrm{X}}=\mathrm{pH}_{\mathrm{S}}+\frac{\left(\mathrm{E}_{\mathrm{S}}-\mathrm{E}_{\mathrm{X}}\right)}{\mathrm{g}}$

where $\mathrm{pH}_{\mathrm{s}}$ and $\mathrm{E}_{\mathrm{s}}$ are the $\mathrm{pH}$ and electromotive force (e.m.f.) of the standard buffer, $\mathrm{pH}_{\mathrm{x}}$ and $\mathrm{E}_{\mathrm{x}}$ are the $\mathrm{pH}$ and e.f.m. 
of the carrier electrolyte and $g$ is the Nernst coefficient, $\mathrm{g}=(\ln 10) \mathrm{RT} / \mathrm{F}$.

Standard stock solutions of the auxins were prepared in $\mathrm{MeOH}$ at a concentration of approximately $200 \mathrm{mg} \mathrm{L}^{-1}$. Working solutions were diluted with the corresponding mobile phase to $10 \mathrm{mg} \mathrm{L}^{-1}$. Standard stock solutions were stored in a freezer and diluted working solutions were stored at $4{ }^{\circ} \mathrm{C}$ in the dark. For each auxins and for every mobile phase composition and $\mathrm{pH}$, the retention time values, $\mathrm{t}_{\mathrm{R}}$, were determined from three different injections. Retention factors were calculated from the equation $k=\left(t_{R}-t_{m}\right) / t_{m}$, where $t_{\mathrm{m}}$ is the retention time of the potassium bromide (hold-up time), $\mathrm{t}_{\mathrm{o}}$, which was measured for every mobile phase composition by injection of $0.01 \%(\mathrm{~m} / \mathrm{v})$ potassium bromide solution in water.

Since an octadecylsilica $\left(\mathrm{C}_{18}\right)$ stationary phase was used, only $\mathrm{pH}$ values in the acidic region were studied and, therefore, only the protolytic equilibrium corresponding to $\mathrm{pK}_{1}$ values of auxins are relevant. The overall observed $\mathrm{k}$ for the studied compounds are:

$\mathrm{k}=\mathrm{X}_{\mathrm{HA}} \mathrm{k}_{\mathrm{HA}}+\mathrm{X}_{\mathrm{A}^{-}} \mathrm{k}_{\mathrm{A}^{-}}$

where $\mathrm{k}_{\mathrm{HA}}$ and $\mathrm{k}_{\mathrm{A}^{-}}$are the capacity factors of the solute in the non-ionized and ionized form, respectively, and $\mathrm{X}_{\mathrm{i}}$ is the mole fraction of the species. Substituting the terms $X_{\mathrm{i}}$, equation 2 can be written as:

$\mathrm{k}=\frac{\mathrm{k}_{\mathrm{HA}}+\mathrm{k}_{\mathrm{A}^{-}} \mathrm{K}_{\mathrm{a}} / \mathrm{a}_{\mathrm{H}^{+}}}{1+\mathrm{K}_{\mathrm{a}} / \mathrm{a}_{\mathrm{H}^{+}}}$

This given equation relates the chromatographic retention of a monoprotic substance, such as studied auxines in the studied range and the $\mathrm{pH}$ of the mobile phase. The equation can be used to determine the $\mathrm{pK}_{\mathrm{a}}$ values, and also predict the chromatographic behaviour and the capacity factors of substances.

The $\mathrm{pK}_{\mathrm{a}}$ values associated with carboxylic acid function were determined by performing a non-linear fit to equation 3 using the NLREG (Non Linear Regression) program ${ }^{27}$ and also the modified STAR (Stability Constants by Absorbance Readings) program was used for simultaneously obtained diode array detector (DAD) data. ${ }^{9,11}$

\section{$L C-D A D$ method}

A novel method based on the absorbance spectra at the maximum of chromatographic peak, obtained with DAD has been applied to obtain the $\mathrm{pK}_{\mathrm{a}}$ values. This method allows the comparison of the values of dissociation constants obtained from chromatographic retention of auxins at different $\mathrm{pH}$ values to those obtained from absorbance spectra at the maximum of the chromatographic peak. It is possible to constitute a valuable means of obtaining better precision. Absorbance spectra were recorded between 190 and $370 \mathrm{~nm}$ and then processed by STAR program. ${ }^{12,14,28}$ This is a non-linear regression program developed for the study of complex equilibria from spectrometric data.

\section{SPARC calculations}

The SPARC program uses algorithms based on fundamental chemical structure theory that combines principles of quantitative structure activity relationships (QSAR), linear free-energy relationships (LFER) and perturbation theory from quantum chemistry. This program estimates the macroscopic and microscopic $\mathrm{pK}_{\mathrm{a}}$ of any organic compound solely from its chemical structure. SPARC is publicly available on the internet. ${ }^{15,16}$

\section{Results and Discussion}

Potentiometric $\mathrm{pK}_{\mathrm{a}}$ values were obtained from several series of independent measurements in 30\%, $40 \%$ and $50 \%(\mathrm{v} / \mathrm{v}) \mathrm{MeOH} /$ water binary mixtures. One series of measurements for one titration of ILA in $40 \%(\mathrm{v} / \mathrm{v})$ $\mathrm{MeOH}$ in water using $\mathrm{KOH}$ solution in the same solvent as titrant is shown in Figure 1, in which the symbols indicate experimental values and solid line indicates the theoretical titration curve.

Table 1 shows the dissociation constants and the respective standard deviations of auxines obtained by potentiometric method using the PKPOT program $^{7}$ in different $\mathrm{MeOH} /$ water binary mixtures.

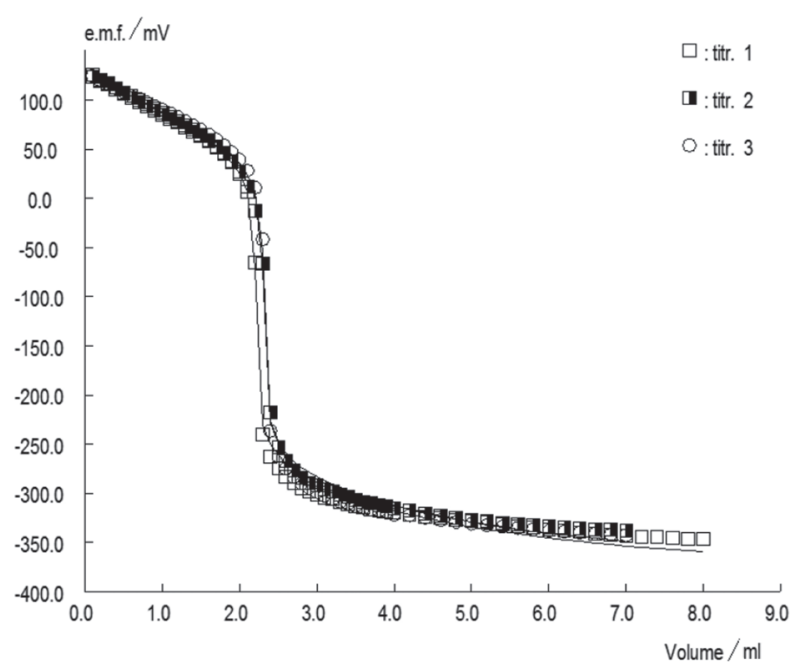

Figure 1. Plot of potentiometric measurement for indole-3-lactic acid (ILA) in $40 \%(\mathrm{v} / \mathrm{v}) \mathrm{MeOH} /$ water. Solid lines indicate the theoretical values calculated by PKPOT program. 
Table 1. $\mathrm{pK}_{\mathrm{a}}$ values of some auxins obtained by potentiometric, $\mathrm{LC}, \mathrm{LC}-\mathrm{DAD}$ and SPARC in different MeOH/water binary mixtures

\begin{tabular}{|c|c|c|c|c|c|}
\hline \multirow[b]{2}{*}{ Compounds } & \multirow[b]{2}{*}{ Method } & \multirow[b]{2}{*}{ water } & \multicolumn{3}{|c|}{$\mathrm{MeOH} /$ water binary mixtures } \\
\hline & & & $30 \%(\mathrm{v} / \mathrm{v})$ & $40 \%(\mathrm{v} / \mathrm{v})$ & $50 \%(\mathrm{v} / \mathrm{v})$ \\
\hline \multirow[t]{4}{*}{ Indole-3-lactic acid (ILA) } & SPARC & 4.06 & & & \\
\hline & Potentiometric & & $4.18(0.05)^{*}$ & $4.45(0.09)^{*}$ & $4.59(0.02)^{*}$ \\
\hline & $\mathrm{LC}$ & & $4.20(0.03)$ & - & - \\
\hline & LC-DAD & & $4.19(0.12)$ & - & - \\
\hline \multirow[t]{4}{*}{ Indole-3-acetic acid (IAA) } & SPARC & 4.84 & & & \\
\hline & Potentiometric & & $4.86(0.08)$ & $5.11(0.08)$ & $5.38(0.07)$ \\
\hline & $\mathrm{LC}$ & & $4.78(0.04)$ & - & - \\
\hline & LC-DAD & & $4.63(0.22)$ & - & - \\
\hline \multirow[t]{4}{*}{ Indole-3-pyruvic acid (IPA) } & SPARC & 3.60 & & & \\
\hline & Potentiometric & & $4.02(0.04)$ & $4.21(0.05)$ & $4.48(0.03)$ \\
\hline & $\mathrm{LC}$ & & $4.13(0.04)$ & - & - \\
\hline & LC-DAD & & $4.14(0.05)$ & - & - \\
\hline
\end{tabular}

* Standard deviations

In order to obtain the $\mathrm{pK}$ values of auxines using $\mathrm{LC}$ methodology, data pairs of $\mathrm{pH}$ and retention factors and the ionic strength over $\mathrm{pH}$ range of 3.5-7, were used. The mobile phase was $\mathrm{MeOH} /$ water mixture $(30 \%$, v/v). The $\mathrm{k}$ values were determined from three separate injections at every mobile phase composition for each $\mathrm{pH}$ value. Retention factors of auxines at various $\mathrm{pH}$ values were shown in Table 2. The column was allowed to stabilize for each $\mathrm{pH}$ value. The repeatability criterion of the retention times of solutes for different injections is RSD $\leq 0.5 \%$. Experimental $\mathrm{k}$ values were shown in Figure 2, equation 2 and 3, which relates the retention factor to $\mathrm{pH}$, was applied to each type of auxines. These equations were experimentally verified and the $\mathrm{pK}_{\mathrm{a}}$ values of the substances studied were determined from experimental $\mathrm{k}$ values, the $\mathrm{pH}$ measured in the hydro-organic media and the calculated activity coefficients.

The $\mathrm{pK}_{\mathrm{a}}$ values were calculated using a non-linear leastsquare fit of the data using the program $\mathrm{NLREG}^{26}$ and were also given in Table 1 and in Figure 3.

In order to obtain the $\mathrm{pK}_{\mathrm{a}}$ values of auxines with LCabsorptiometric diode array detection, the absorption spectra at the maximum of the chromatographic peak were used in $30 \%(\mathrm{v} / \mathrm{v})$ binary solvent mixture. The absorbance spectra were recorded at various $\mathrm{pH}$ values between 190 and $320 \mathrm{~nm}$ intervals and the spectrum data were then processed by using the STAR program. Figure 4 shows the variation of the absorbance spectra for ILA and IAA at the maximum of the chromatographic peak over the $\mathrm{pH}$ range from 3.5 to 7 as the application of LC-UV (DAD) method.

$\mathrm{pK}_{\mathrm{a}}$ values predicted by SPARC program for ILA, IAA and IPA were 4.06, 4.84, and 3.60 respectively. The dissociation constant is attributed to the deprotonation of
Table 2. Retention factors, $\mathrm{k}$, of auxines at various $\mathrm{pH}$ values in $30 \%$ (v/v) $\mathrm{MeOH} /$ water mobile phase

\begin{tabular}{|c|c|c|c|c|}
\hline $\mathrm{pH}$ & Compounds & $\mathrm{R}_{\mathrm{t}}$ & $\mathrm{k}$ & $\alpha$ \\
\hline \multirow[t]{3}{*}{3.5} & ILA & $8.82(0.02)^{*}$ & 5.30 & - \\
\hline & IAA & $14.40(0.01)$ & 9.30 & 1.75 \\
\hline & IPA & $21.31(0.01)$ & 14.23 & 1.53 \\
\hline \multirow[t]{3}{*}{4.0} & ILA & $7.32(0.01)$ & 4.20 & - \\
\hline & IAA & $13.96(0.02)$ & 8.92 & 2.12 \\
\hline & IPA & $16.88(0.01)$ & 10.99 & 1.23 \\
\hline \multirow[t]{3}{*}{4.5} & ILA & $5.48(0.01)$ & 2.90 & - \\
\hline & IAA & $10.25(0.05)$ & 6.30 & 2.17 \\
\hline & IPA & $11.06(0.01)$ & 6.86 & 1.09 \\
\hline \multirow[t]{3}{*}{5.0} & ILA & $4.01(0.10)$ & 1.87 & - \\
\hline & IAA & $6.15(0.10)$ & 3.40 & 1.82 \\
\hline & IPA & $7.50(0.02)$ & 4.37 & 1.29 \\
\hline \multirow[t]{3}{*}{5.5} & ILA & $3.37(0.01)$ & 1.41 & - \\
\hline & IAA & $4.72(0.01)$ & 2.38 & 1.69 \\
\hline & IPA & $4.97(0.01)$ & 2.55 & 1.07 \\
\hline \multirow[t]{3}{*}{6.0} & ILA & $3.34(0.02)$ & 1.39 & - \\
\hline & IAA & $3.84(0.01)$ & 1.75 & 1.26 \\
\hline & IPA & $4.31(0.01)$ & 2.08 & 1.19 \\
\hline \multirow[t]{3}{*}{7.0} & ILA & $3.01(0.01)$ & 1.16 & - \\
\hline & IAA & $3.07(0.01)$ & 1.21 & 1.04 \\
\hline & IPA & $4.12(0.01)$ & 1.96 & 1.62 \\
\hline
\end{tabular}

* Standard deviations

the carboxyl group and values predicted by SPARC are given in Table 1. Values obtained by potentiometry, LC and LC-DAD for the $\mathrm{pK}_{\mathrm{a}}$ attributed to the carboxylic group are in good agreement, since the differences are usually lower than $0.1 \mathrm{pK}_{\mathrm{a}}$ units for $30 \%(\mathrm{v} / \mathrm{v}) \mathrm{MeOH}$ content. As 

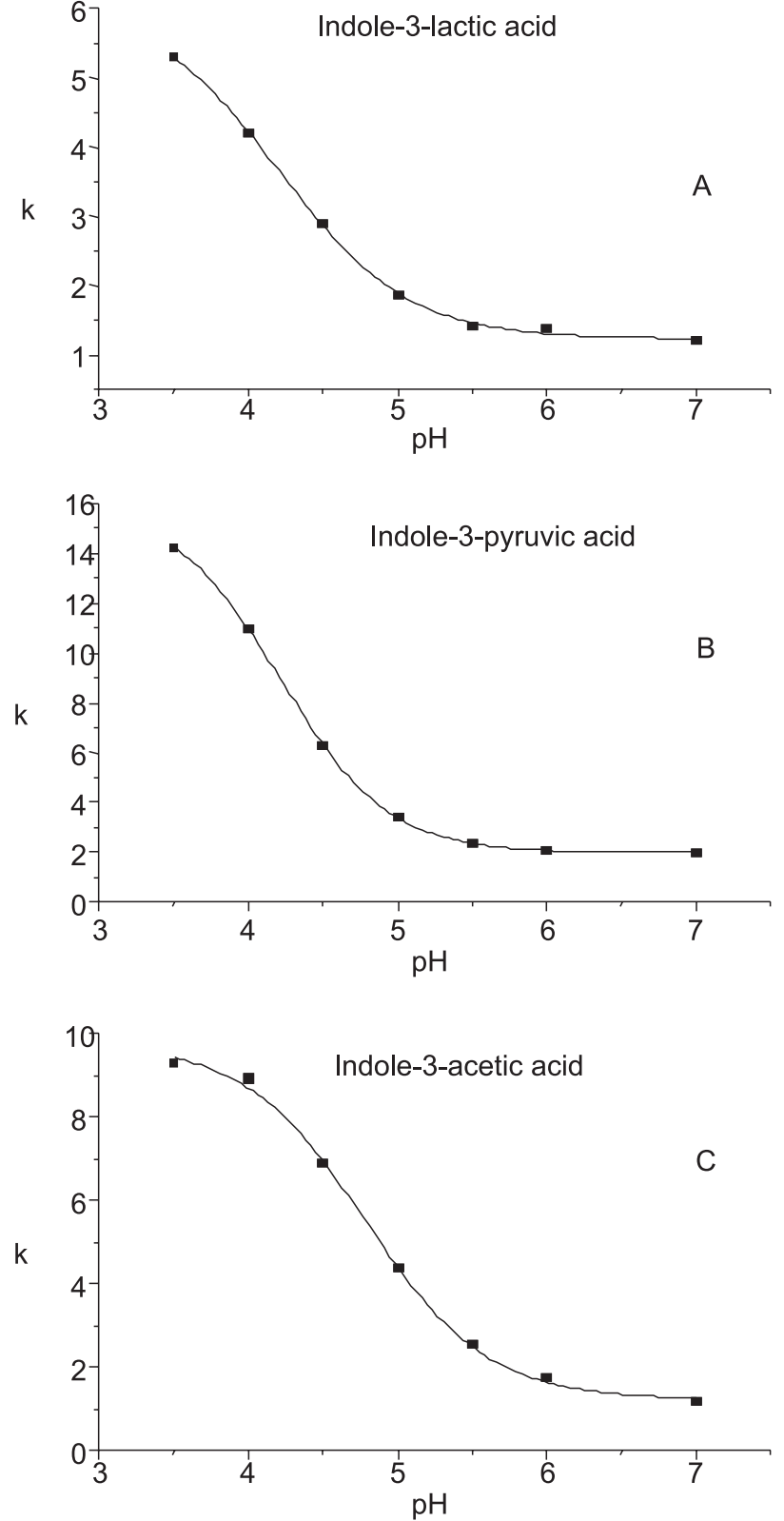

Figure 2. Plot of capacity factors of auxines vs. $\mathrm{pH}$ in $30 \%(\mathrm{v} / \mathrm{v}) \mathrm{MeOH} /$ water mobile phase. (A) indole-3-lactic acid, (B) indole-3-pyruvic acid, (C) indole-3-acetic acid.

expected, the $\mathrm{pK}_{\mathrm{a}}$ values predicted by SPARC in aqueous medium are lower than those obtained from hydro-organic media.

The influence of methanol content on $\mathrm{pK}_{\mathrm{a}}$ values was as expected: $\mathrm{pK}_{\mathrm{a}}$ values increase with increasing percentage of organic modifier. ${ }^{29-34}$ It has been found that $\mathrm{pK}_{\mathrm{a}}$ values of a given compounds show a linear relationship with the mole fraction of methanol-water (up to 50\% methanol) organic binary mixtures. The plot of experimental $\mathrm{pK}_{\mathrm{a}}$ values of studied auxines against the mole fraction of methanol are given in Figure 5.
pKa determination by LC, Indole-3-acetic acid

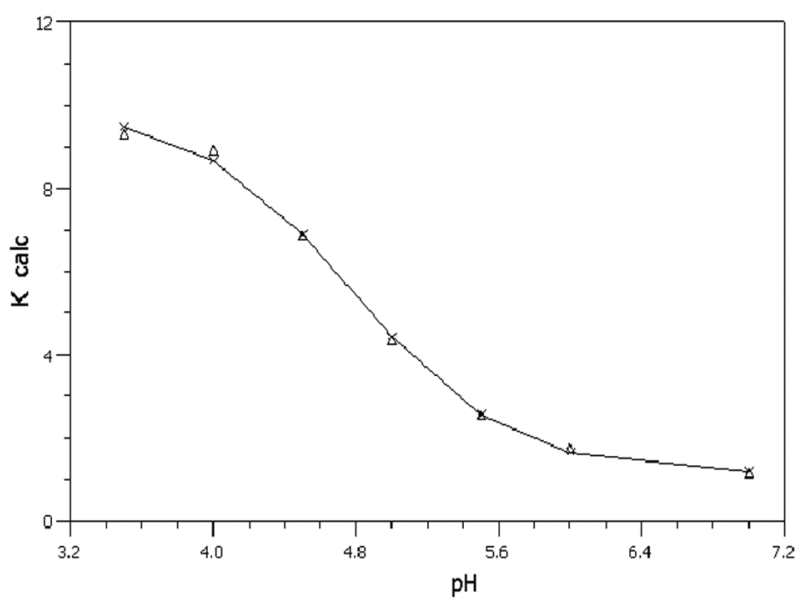

Figure 3. Plot of NLREG analysis of indole-3-acetic acid. Symbols indicate to the experimental capacity factor values and the line indicates calculated theoretical capacity factors, $\mathrm{k}$, calculated by NLREG.

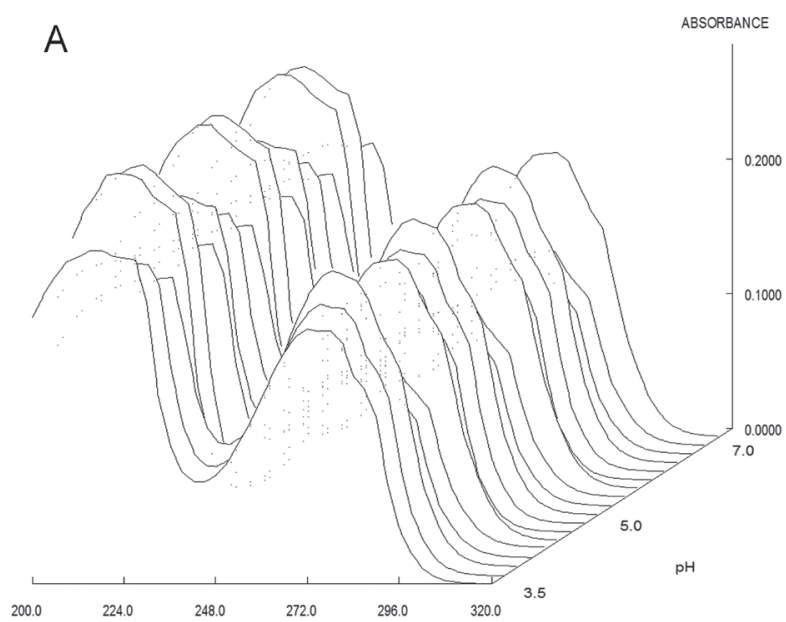

2000

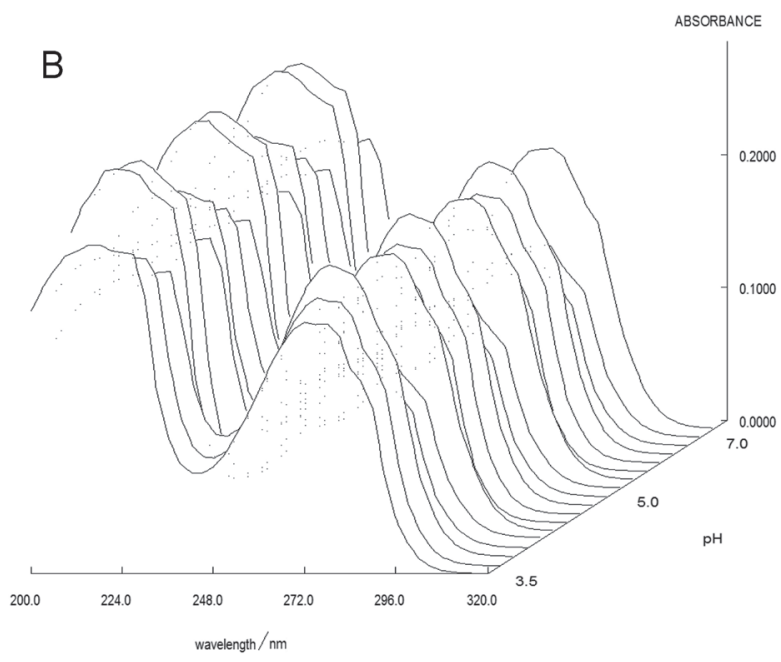

Figure 4. Absorption spectra (wavelenght-absorbance-pH) obtained for indole-3-lactic acid (A) and indole-3-acetic acid (B) at the maximum of $\mathrm{LC}$ peaks in $30 \%(\mathrm{v} / \mathrm{v}) \mathrm{MeOH} /$ water mixture. 


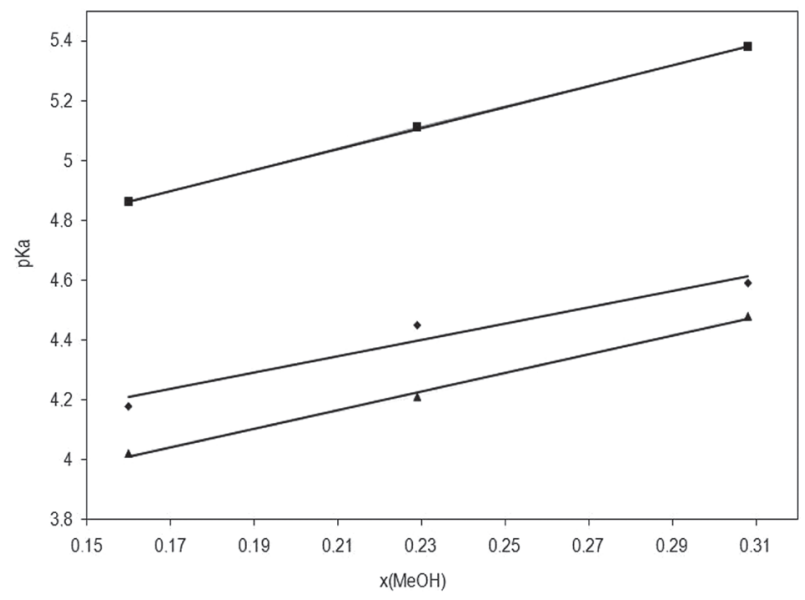

Figure 5. Plot of experimental $\mathrm{pK}_{\mathrm{a}}$ values of auxines against the mole fraction of methanol. Symbols indicate: ( $\mathbf{\square}$ ) Indole-3-acetic acid; $(\diamond)$ Indole-3-lactic acid; ( $\mathbf{\Delta})$ Indole-3-pyruvic acid.

The intercept, slope and correlation coefficients for ILA 3.769, 2.746, 0.976; IAA 4.301, 3.511, 0.999; IPA 3.513, $3.115,0.998$ are given, respectively. These results indicate that, in general, the assumption of a linear relationship between $\mathrm{pK}_{\mathrm{a}}$ values of auxines against the mole fraction of methanol is a good approximation in this interval.

There is no reference for $\mathrm{pK}$ determination of auxines, however earlier publications of other authors are seldom encountered..$^{35,36}$ The $\mathrm{pK}_{\mathrm{a}}$ of IAA 4.75 is available in Merck index. ${ }^{37} \mathrm{~A}$ further comparison between the $\mathrm{pK}_{\mathrm{a}}$ values given in the literature (where available) and the predicted by SPARC shows that generally they are in good agreement and except in case of IPA, predicted values are within 0.1 $\mathrm{pK}_{\mathrm{a}}$ units from literature values.

Very often, the main difficulty in the determination of aqueous $\mathrm{pK}_{\mathrm{a}}$ of auxines is their aqueous insolubility that forces the use of a hydro organic solvent for the experimental measurements. Therefore, 30\% (v/v) MeOH/ water medium was selected as minimum organic solvent to dissolve the studied compounds. $\mathrm{MeOH} /$ water hydro organic mixtures have been widely recommended and used because, among organic solvents, methanol shows the closest properties to water. Therefore, any extrapolation means could be used to get the $\mathrm{pK}_{\mathrm{a}}$ values in water.

\section{Conclusion}

In the study, the determination of dissociation constants of IAA, ILA and IPA has been performed by potentiometry, HPLC and HPLC-DAD methods and the application of some literature programs were investigated. The results obtained by the different methodologies and the values predicted by SPARC are summarized in Table 1. The values obtained in this work for the $\mathrm{pK}_{\mathrm{a} 1}$ attributed to the carboxylic group are in good agreement for $30 \%(\mathrm{v} / \mathrm{v})$ $\mathrm{MeOH}$ content, as the differences are usually lower than $0.1 \mathrm{pK}_{\mathrm{a}}$ unit.

However, potentiometry and LC methodology gives better accuracy and precision than LC-DAD method. This is due to the fact that the electrode system is calibrated before each potentiometric titrations and the electrode remains into the experimental solution during titration. The capacity factors used to estimate the $\mathrm{pK}_{\mathrm{a}}$ values are derived from the retention time of the solute and the hold-up time, so that it gives lower precision. In LC-DAD procedure, the spectra measured by the diode-array detector were used instead of capacity factors, but the errors in the $\mathrm{pH}$ measurement will be affected the procedure.

The contribution of the study in evaluating $\mathrm{pK}_{\mathrm{a}}$ values, still not available in the literature, could be very useful. Therefore, the dissociation constants for studied compounds are useful for facilitating occurrence, effects, and control of plant hormones in scientific studies for investigators.

\section{Acknowledgments}

We gratefully acknowledge to Dr. Jose Luis Beltran from University of Barcelona for kindly providing the programs PKPOT and STAR.

\section{References}

1. Poole, C. F.; Poole, S. K.; Chromatography Today; Elsevier: Amsterdam, 1991.

2. Schoenmakers, P. J.; Tijssen R.; J. Chromatogr., A 1993, 656, 577.

3. Janos, P.; J. Chromatogr., A 2004, 137, 15.

4. Rived, F.; Roses, M.; Bosch E.; Anal. Chim. Acta 1998, 374, 309.

5. Wrobel, R.; Chmurzynski, L.; Anal. Chim. Acta 2000, 405, 303.

6. Martell, A. E.; Motekaitis, R. J.; Determination and Use of Stability Constants, $2^{\text {nd }}$ ed., VCH Publishers: New York, 1992.

7. Barbosa, J.; Barron, D.; Beltran, J. L.; Sanz-Nebot, V.; Anal. Chim. Acta 1995, 317, 75.

8. Gans, P.; Sabatini, A.; Vacca, A.; Talanta 1996, 43, 1739.

9. Kaliszan, R.; Wiczling, P.; Markuszewski, M. J.; J. Chromatogr., A 2004, 1060, 165.

10. Hardcastle, J. E.; Jano, I.; J. Chromatogr., B 1998, 717, 39.

11. Sanli, N.; Fonrodona, G.; Barron, D.; Ozkan, G.; Barbosa, J.; J. Chromatogr., A 2002, 75, 299.

12. Perez-Urquiza, M.; Beltran, J. L.; J. Chromatogr., A 2001, 917 , 331.

13. Jimenez-Lozano, E.; Marques, I.; Barron, D.; Beltran, J. L.; Barbosa, J.; Anal Chim. Acta 2002, 464, 37. 
14. Beltran, J. L.; Sanli, N.; Fonrodona, G.; Barron, D.; Ozkan, G.; Barbosa, J.; Anal. Chim. Acta 2003, 484, 253.

15. Hilal, S. H.; Karicckhoff, S. W.; Carreira, L. A.; QSAR Comb. Sci. 2004, 23, 709.

16. http://ibmlc2.chem.uga.edu/sparc/, accessed in May 2008.

17. Kelen, M.; Demiralay, E. C.; Sen, S.; Ozkan, G.; Turk. J. Chem. 2004, 28, 603.

18. Foskett, D. E.; Plant Growth and Development, $1^{\text {st }}$ ed., Academic Press: California, 1994.

19. Preece, J. E.; Read, P. E.; The Biology of Horticulture, Wiley: New York, 1993.

20. Davies, P. J. In Plant Hormones: Physiology, Biochemistry and Molecular Biology; $2^{\text {nd }}$ ed., Davies, P.J., ed., Kluwer: Dordrecht, Netherlands, 1995.

21. Gran, G.; Analyst 1952, 77, 661.

22. Gameiro, P.; Reis, S.; Lima J. L. F. C.; De Castro, B.; Anal. Chim. Acta 2000, 405, 167.

23. Rondinini, S.; Mussini, P. R.; Mussini, T.; Pure Appl. Chem. 1987, 59, 1549.

24. Mussini, P. R.; Mussini T.; Rondinini, S.; Pure Appl. Chem. 1997, 69, 1007.

25. Barbosa, J.; Marqués, I.; Barron, D.; Sanz-Nebot, V.; Trends Anal. Chem. 1999, 18, 543.

26. Bates, R.G.; Robinson, R.A.; Acid-Base Behavior in MethanolWater Solvents, Chemical Physics of Ionic Solutions, Wiley: New York, 1966.
27. http://www.nlreg.com, accessed in May 2008.

28. Beltran, J. L. ; Codony, R.; Prat, M. D.; Anal. Chim. Acta 1993, $276,441$.

29. Kamlet, M. J.; Abboud, J. L. M.; Taft, R. W.; Progr. Phys. Org. Chem. 1981, 13, 452.

30. Reichardt, C.; Solvents and Solvent Effects in Organic Chemistry, $2^{\text {nd }}$ ed., VCH Verlagsgesellschaft: Weinheim, 1988, p. 454.

31. Barbosa, J.; Beltran, J.L.; Sanz-Nebot, V.; Anal. Chim. Acta 1994, 288, 271.

32. Bacarella, A. L.; Grunwald, E.; Marshall, H. P.; Purlee, E. L.; J. Org. Chem. 1955, 20, 747.

33. Marques, I.; Fonrodona, G.; Buti, S.; Barbosa, J.; Trends Anal. Chem. 1999, 18, 472.

34. Erdemgil, F. Z.; Sanli, S.; Sanli, N.; Ozkan, G.; Barbosa, J.; Guiteras, J.; Beltran, J. L.; Talanta 2007, 72, 489.

35. Chiang, P. C.; Su, C. C.; Block, K. M.; Pretzer, D. K.; J. Liq. Chromatogr. Relat. Technol. 2005, 28, 3035.

36. Thomas-Vert, F.; Ponce, C. A.; Estrada, M. R.; Silber, J.; Singh, J.; Anunciatta, J.; J. Mol. Struct. 1991, 246, 203.

37. Budavari, S., ed.; The Merck Index. An Encyclopedia of Chemicals, Drugs, and Biologicals, $12^{\text {th }}$ ed., Merck \& Co.: Whitehouse Station, NJ, 1996.

Received: June 3, 2008

Web Release Date: November 26, 2008 